\title{
ANALISIS KOMPETENSI PROFESIONAL \\ DAN KINERJA DOSEN
}

\author{
Shinta Nento ${ }^{1}$
}

\begin{abstract}
ABSTRAK
Performance of lecture in educational institutions is an interesting factor to study, because: First, the lecture is a determinant of the success of the learning process, without qualified lecturer, it is impossible to produce quality student. Second, teachers provide examples of attitudes, behavior and personality.
\end{abstract}

\section{PENDAHULUAN}

Human Resources yang berkualitas adalah modal penting dan sekaligus sebagai keybord menakar keberhasilan suatu bangsa. Keunggulan mahasiswa berkualitas ini telah ditunjukan oleh bangsa lain yang care kepada keadaban dan harkat kebudayaan mereka. Dominasi keadaban dan kebudayaan dapat kita lihat dari sisi penguasaan ekonomi global. Sebutlah lima Negara berikut: Amarika Serikat, Jepang, Jerman, China, dan inggris (Soedijarto, 2007:6). Kelima Negara tersebut hingga saat ini dapat diakui oleh dunia sebagai lambing kedigdayaan ekonomis global. Indonesia sebagai bangsa besar terdapat harapan bagi bangsa kita jika sumber daya manusia yang bila dilihat dari jumlah penduduk yang sangat besar dapat ditingkatkan maka dapat diduga secara bertahap namun pasti perekonomian kita akan bertumbuh.oleh karena itu, tantangan utama yang dihadapi sekarang inidan dimasa mendatang ialah penyiapan tenaga pelaksana pembangunan yang berkualitas. Maupun dan terampil melakukan pekerjaan sekaligus mempunyai inovasi dan kreativitas tinggi dan daya analisa ke depan.

Dunia pendidikan dalam konteks ini memiliki funsi utama. Pertama, kewajiban menyediakan lulusan yang berkualitas dan disiplin yang tinggi, maupun menjadi dinamisator, inovator, motivator penggerak kebudayaan bangsa. Kedua, dunia pendidikan khususnya pendidikan tinggi berkewajiban menyediakan sarjana yang siap kerja dan sekaligus memiliki kemampuan menciptakan lapangan kerja.

Dunia pendidikan berfungsi memproduksi tenaga-tenaga yang berkualitas untuk berbagai jenis dan tingkatan keahlian. Dunia pendidikan, khususnya pendidikan tinggi menghasilkan

\footnotetext{
${ }^{1}$ Dosen pada Program Studi PAI \& MPI Jurusan Tarbiyah STAIN Manado
} 
sarjana. Tenaga-tenaga terpilih yang diharapkan menjadi dinamisator pembangunan. Gerak dan laju pembangunan bayak ditentukan oleh jumlah, mutu, kemampuan, dan kecocokan sarjana dan lulusan pendidikan yang dihasilkan dengan kebutuhan nyata dalam masyarakat.pendidikan harus mampu mengeluarkan tenaga yang sesuai dengan kebutuhan masyarakat. Secara umum disebutkan bahwa program pendidikan disemua tingkat harus direncanakan berdasarkan kebutuhan tenaga yang jelas. Di pihak lain dunia pendidikan, juga dipengaruhi oleh permintaan masyarakat (social demand), walaupun permintaan masyarakat akan pendidikan tidak selalu sesuai dengan pendidikannya.

Dalam dunia pendidikan perlu dikembangkan sikap dan kemampuan profesionalisme. Untuk itu, perlu dikembangkan, pengetahuan dan kewirausahaan, dan juga sikap, inisiatif dan kepercayaan atas kemampuan sendiri.

Dalam suatu fenomena yang lain, permasalahan yang muncul kepermukaan sekarang adalah isu tentang rendahnya mutu pendidikan dalam berbagai jenjang di Indonesia. Sebagaimana didapatkan pada hasil survey yang dilakukan terhadap mahasiswa tingkat akhir perguruan Tinggi Negri dan perguruan Tinggi Swasta menunjukan bahwa 36 persen menyatakan siap pakai, 50 persen tidak siap pakai dan 15 persen abstain. Hasil survei ini merupakan salah satu indikator atas rendahnya kualitas pendidikan sehingga para lulusan sebagian belum memadai untuk langsung mengemban tugas yang diberikan. (Suganda [1999] dalam Sumartiningsih [2004:2]).

Gambaran tentang rendahnya kapasitas dan sistem pendidikan di Indonesia sebagaimana diuraikan di atas, mengisyaratkan bahwa masih lemahnya aspek pendidikan di Indonesia. Meskipun tidak mudah untuk menggenere=alisasikan lemahnya manajemen pada berbagai jenjang dan jenis pendidikan, namun demikian tidaklah berlebihan untuk menduga bahwa gambaran yang sama akan dijumpai pada lembaga pendidikan Tinggi Islam.

Dari kompleks permasalahan pendidikan, baik yang menyangkut kompetensi profesional dosen, motivasi kerja dosen. Kinerja dosen, pemerataan, relevansi, produktifitas, evektifitas dan efisiensi serta mutu pendidikan, pada hakikatnya keberhasilan penyelenggaraan pendidikan: sangat ditentukan oleh kinerja para pelaku pendidikan, khususnya dosen sebagai ujung tombak pengelolah pendidikan dan pengajaran. Dosen menerapkan jabatan fungsional yang harus berlandaskan pada kompetensi profesional dalam menjalankan kewenangan keprofesiannya. Dengan kompetensi profesional yang dimiliki oleh dosen diharapkan mampu. Melaksanakan tugasnya dengan baik sehingga menghasilkan kinerja yang baik pula. 
Kinerja dosen dalam suatu institusi pendidikan merupakan faktor yang, menarik untuk diteliti karena lima alasan: Pertama, dosen merupakan tombak bagi keberhasilan proses blajar mengajar, tanpa dosen yang berkualitas dan rela berkorban, mustahil suatu proses belajar mengajar dapat menghasilkan peserta didik yang berkualitas. Kedua, dosen tidak hanya berperan dan mentransfer ilmu kepada mahasiswa tetapi memberikan contoh sikap, ucapan perilaku kepribadian. Ketiga, kualitas kinerja dosen bukanlah suatu yang final dan tidak dapat diperbaiki karena sebagai manusia, dosen selalu tumbuh dan berubah. Keempat, jika kinerja dosen tidak didukung oleh kompetensi profesionaldan motivasi kerjanya, maka proses belajar mengajar tidak bisa lancer sesuai yang diharapkan. Oleh karena itu, dosen dapat memperbaiki sesuai yang diharapkan. Kelima, guru dan dosen memiliki kualifikasi akademik, kompetensi, serfitikat pendidik, sehat dan rohani serta memeliki kemampuan untuk mewujudkan tujuan pendidikan nasional (pasal 8, UUGD 14/2005). Oleh karena itu, guru dan dosen harus memiliki empat kompetensi, yaitu (1) pedagogik (kemampuan mengolah pembelajaran peserta didik); (2) kepribadian (kemampuan kepribadian mantap, berakhlak mulia, arif, dan berwibawa serta menjadi teladan peserta didik); (3) sosial (kemampuan guru untuk berkomunikasi dan berinteraksi secara efektif dan efesien dengan peserta didik, sesama guru, orang tua/wali peserta didik dan masyarakat sekitar; dan (4) profesional (kemampuan penguasaan materi pelajaran secara luas dan mendalam). Alasan tersebut tentunya dapat memberikan harapan dan optimisme baru kepada siapapun yang menaruh perhatian serius kepada dunia pendidikan, terutama tentang peningkatan kualitas kinerja dosen, baik dalam hal penguasaan materi, metode mengajar, kemampuan komunikasi atau kemampuan teknisi lainnya sehingga proses belajar mengajar menjadi berkualitas dan memuaskan.

Dalam proses pendidikan, dosen merupakan salah satu komponen yang penting. Menurut Undang-undang No. 14 Tahun 2005 tentang Guru dan Dosen, pasal 1 ayat 2 dan ayat 4 mengatakan bahwa "Dosen adalah pendidik yang profesional dan ilmuan dengan tugas utama mentransformasikan, mengembangkan, dan menyebarluaskan ilmu pengetahuan, teknologi, dan seni melalui pendidikan, penelitian dan pengabdian kepada masyarakat.” Sedang pengertian "Profesional adalah pekerjaan atau kegiatan yang dilakukan oleh seseorang dan menjadi sumber penghasilan kehidupan yang memerlukan keahlian, kemahiran, atau kecakapan yang memenuhi standar mutu atau norma tertentu serta memerlukan pendidikan profesi”. Dosen tidak cukup hanya memiliki predikat professional saja dalam menjalankan fungsinya. Dosen harus memiliki 
juga kompetensi yang melekat pada dirinya. Hal ini sejalan dengan UU No. 14 Tahun 2005 pasal 10 bahwa pengertian kompetensi adalah seperangkat pengetahuan, keterampilan, dan perilaku yang harus dimiliki, dihayati, dan dikuasai oleh guru dan dosen dalam melaksanaan tugas keprofesionalnya. Bila menyamakan fungsi dan peran dosen dengan guru disekolah, maka tugas guru/dosen sebagai profesi melalui mendidik, mengajar dan melatih. Mendidik berarti meneruskan dan mengembangkan nilai-nilai hidup.

Mengajar berarti meneruskan dan mengembangkan ilmu pengetahuan dan teknologi. Melatih berarti mengembangkan keterampilan-keterampilan pada siswa. Dengan demikian, setiap peningkatan mutu pendidikan yang diarahkan pada perubahan-perubahan kualitatif harus menempatkan dosen dan guru pada titik sentral, karena peranannya sangat strategi dan mempunyai tanggung jawab yang besar ialah upaya mewujudkan tujuan pendidikan nasional.

Kinerja dosen dalam suatu lembaga, menurut pandangan teori perilaku organisasi ditentukan oleh faktor-faktor internal dan eksternal. Faktor internal yang mempengaruhi kinerja dosen ialah kompetensi profesional dan motivasinya, sedangkan faktor eksternal ialah iklim organisasi, akreditasi, dan hubungan antar lembaga Perguruan Tinggi (PT).

Sedangkan dari sudut pandang tugasnya sebagai dosen tentunya banyak faktor yang dapat

mempengaruhi kinerjanya yaitu (1) penguasaan bahan; (2) mengelolah program belajar mengajar; (3) mengelola kelas; (4) menggunakan media dan sumber; dan (5) menggunakan micro teaching dalam program pengalaman lapangan.

Dalam mendukung kinerja dosen perlu dukungan kompetensi profesional dosen yang handal. Kompetensi profesional dosen dinyatakan Pedoman Pelaksanaan Pembaharuan Sistem Pendidikan Tenaga Kependidikan di Indonesia dari Dirijen Dikti profil kompetensi profesional dosen yang meliputi: (1) kualitas hasi kerja (2) kemampuan; (3) prakarsa/inisiatif; (4) komunikasi; dan (5) ketepatan waktu.

\section{DEFINISI-DEFINISI}

Definisi operasiona variabel bertujuan untuk menjelaskan makna variabel yang sedang diteliti. Definisi operasional adalah unsur penelitian yang memberitahukan bagaimana cara mengukur suatu variabel, dengan kata lain definisi operasional adalah suatu informasi ilmiah yang membantu peneliti lain yang ingin menggunakan variabel yang sama. Adapun definisi operasional dalam penelitian ini adalah sebagai berikut: 
1. Kompetensi Profesional adalah keluasan wawasan akademik dan kedalaman pengetahuan dosen terhadap materi keilmuan yang ditekuninya yang mencakup: (a) penguasaan bahan; (b) mengolah program belajar mengajar; (c) mengolah kelas; (d) menggunakan media dan sumber belajar; (e) menggunakan micro teaching dalam program pengalaman lapangan.

2. Kinerja dosen adalah kualitas hasil kerja dosen yang diperoleh berdasarkan pengajaran (proses belajar mengajar) yang mencakup: (a) kemampuan; (b) prakarsa/inisiatif; (c) ketetapan waktu; (d) kualitas hasil kerja; dan (e) komunikasi.

Berkenaan dengan hal tersebut indikator-indikator kinerja dosen adalah sebagai berikut:

1. Kemampuan

- Penguasaan materi

- Penguasaan metode pengajaran

2. Inisiatif

- Berpikir positif yang lebih baik

- Mewujudkan kreatifitas

- Mencapai prestasi

3. Ketetapan waktu

- Waktu kedatangan

- Waktu pulang

4. Kualitas hasil kerja

- Kepuasan mahasiswa

- Pemahaman mahasiswa

- Prestasi mahasiswa

5. Komunikasi

- Mutu penyampaian materi

- Penguasaan keadaan kelas

Dalam menilai kompetensi profesional seorang dosen telah diberikan tanggung jawab sebagaimana yang diatur dalam buku Pedoman Beban Kerja Dosen Ditpertais Dirijen Pendis Kemenag RI tahun 2011. Secara rinci uraiannya adalah sebagai berikut: 
Tugas pendidikan dan pengajaran secara umum dapat dilakukan dosen dengan bentuk kegiatan sebagai berikut:

a. Melaksanakan perkuliahan/tutorial dan menguji;

b. Menyelenggarakan kegiatan pendidikan di laboratorium, praktik keguruan, praktik bengkel/studio/teknologi/pengajaran;

c. Membimbing seminar mahasiswa;

d. Membimbing kuliah kerja nyata $(\mathrm{KKN})$, praktik kerja nyata $(\mathrm{PKN})$, praktik kerja lapangan (PKL), program lapangan profesi (PLP), atau kerja praktik (KP).

e. Membimbing tugas akhir penelitian mahasiswa termasuk membimbing pembuatan laporan hasi penelitian akhir;

f. Penguji pada ujian akhir/munaqosyah;

g. Mengembangkan program perkuliahan;

h. Mengembangkan bahan pengajaran;

i. Membina kegiatan mahasiswa dibidang akademik dan kemahasiswaan;

j. Membimbing dosen yang lebih rendah jabatannya;

k. Melaksanakan kegiatan detasering, sabbatical leave, dan pencangkokan dosen;

Dalam tugas penelitian dan pengembangan ilmu yang wajib dilakukan dosen dengan bentuk kegiatan sebagaimana berikut;

a. Menghasilkan karya penelitian;

b. Menerjemahkan/menyadur buku ilmiah;

c. Mengedit/menyunting karya ilmiah;

d. Membuat rancangan, karya teknologi, dan karya seni;

e. Menyampaikan orasi ilmiah, pembicaraan seminar;

Untuk tugas pengabdian wajib dilakukan dosen dengan bentuk kegiatan sebagaimana berikut:

a. Melaksanakan pengembangan hasil pendidikan dan penelitian yang dapat dimanfaatkan oleh masyarakat;

b. Memberi latihan/penataran/penyuluhan/ceramah kepada masyarakat;

c. Memberi pelayanan secara langsung kepada masyarakat atau kegiatan lain yang menunjang pealksanaan tugas umum pemerintah dan pembangunan; 
d. Membuat/menulis karya pengabdian kepada masyarakat;

Sebagai tugas penunjang Tridharma Perguruan Tinggi dosen dapat melaksanakan bentukbentuk kegiatan berupa;

a. Menjadi penasihat akademik;

b. Menjadi wakil atau sekertaris koordinator KOPERTAIS;

c. Menjadi anggota dalam suatu panitia/badan pada perguruan tinggi;

d. Menjadi anggota panitia/badan pada lembaga pemerintahan;

e. Menjadi anggota organisasi profesi;

f. Mewakili perguruan tinggi/lembaga pemerintah duduk dalam panitia antar lembaga;

g. Menjadi anggota delegasi nasional dalam pertemuan internasional;

h. Berperan aktif dalam pertemuan ilmiah;

i. Mendapatkan tanda jasa/penghargaan;

j. Menulis buku pelajaran SLTA ke bawah;

k. Mempunyai prestasi di bidang olah raga/kesenian/sosial;

Selain dari pedoman beban Kerja Dosen sebagaimana diatur dalam buku yang dikeluarkan oleh Ditpertasi Dirijen Pendis Kemenag RI tahun 2011, kompetensi profesional dosen juga dapat ditambahkan oleh aturan dalam Buku II Pedoman Pelaksanaan Pola Pembaharuan Sistem Pendidikan Tenaga Kependidikan Di Indonesia dari Dirjen Dikti, sebagai berikut:

1. Penguasaan bahan, yakni menguasai bahan-bahan bidang studi dan metodologi.

2. Mengolah program belajar mengajar yang meliputi;

a. Merumuskan tujuan intruksional

b. Mengenal dan dapat menggunakan metode mengajar

c. Memilih dan menyusun tujuan intruksional yang tepat

d. Melaksanakan program blajar mengajar

e. Mengenal kemampuan mahasiswa

f. Merencanakan dan melaksanakan pengajaran remedial

3. Mengolah kelas yang meliputi;

a. Mengatur tata ruang kelas untuk mengajar

b. Menciptakan iklim belajar yang serasi 
4. Menggunakan media dan sumber belajar yang meliputi;
a. Mengenal, memilih dan menggunakan media
b. Membuat alat bantu yang sederhana
c. Menggunakan mengolah laboratorium dalam rangka proses belajar mengajar

5. Menggunakan micro teaching dalam pengalaman program lapangan yang meliputi;
a. Menguasai landasan-landasan kependidikan
b. Mengolah interaksi belajar
c. Menilai prestasi belajar mahasiswa
d. Mengenal fungsi dan program bimbingan dan penyuluhan
e. Mengenal dan menyelenggarakan administrasi
f. Memahami prinsip-prinsip dan menafsirkan hasil-hasil penelitian pendidikan guna keperluan pengajaran.

\section{KINERJA DOSEN}

Kinerja adalah ukuran mengenai apa yang dikerjakan dan apa yang tidak dikerjakan oleh karyawan. ${ }^{2}$ Menurut Mangkunegara, prestasi kerja berasal dari kata job performance atau actual performance yaitu hasil kerja secara kualitas dan kuantitas yang dicapai oleh seseorang pegawai dalam melaksanakan tugasnya sesuai dengan tanggung jawab yang diberikan kepadanya. ${ }^{3}$

Kinerja dosen merupakan salah satu faktor penentu keberhasilan proses belajar mengajar di perguruan tinggi. Prawirosentono menyatakan, terdapat hubungan yang erat antara kinerja perseorangan dengan kinerja perseorangan dengan kinerja perusahaan. ${ }^{4}$ Pernyataan tersebut menunjukan bahwa apabila kinerja dosen baik, maka kinerja perguruan tinggi juga akan menjadi baik.

Kinerja adalah hasil atau tingkat keberhasilan seseorang secara keseluruhan selama periode tertentu dalam melaksanakan tugas dibandingkan dengan berbagai kemungkinan, seperti standar hasil kerja, target atau sasaran atau kriteria yang telah ditentukan terlebih dahulu dan telah disepakati bersama. Jika dilihat dari asal katanya, kata kinerja adalah terjemahan dan performance, dengan beberapa makna, yaitu: (1) melakukan, menjalankan, melaksanakan; (2)

\footnotetext{
${ }^{2}$ Robbins, Stephen P. (2002), Perilaku Organisasi, Edisi Indonesia (Jakarta: PT, Indeks), h. 340.

${ }^{3}$ Mangkunegara, A. P (2005), Perilaku dan Budaya Organisasi (Bandung: Rosdayakarta), h. 120.

${ }^{4}$ Prawirosentono, S. (1999), Kebijakan Kinerja Karyawan, Edisi I (Yogyakarta : BPFE), h. 45.
} 
memenuhi atau melaksanakan kewajiban suatu niat atau nazar; (3) melaksanakan atau menyempurnakan tanggung jawab; dan (4) melakukan sesuatu yang diharapkan oleh seseoarang.

Kinerja dalam bahasa Indonesia disebut juga prestasi kerja. Kinerja atau prestasi kerja (performance) diartikan sebagai ungkapan kemampuan yang didasari oleh pengetahuan, sikap, keterampilan dan motivasi dalam menghasilkan sesuatu. Prestasi kerja (performance) diartikan sebagai suatu pencapaian persyaratan pekerjaan tertentu yang akhirnya secara langsung dapat tercermin dari output yang dihasilkan baik kuantitas maupun mutunya. Pengertian diatas menyoroti kinerja berdasarkan hasil yang dicapai seseorang setelah melakukan pekerjaan. ${ }^{5}$

Prestasi kinerja adalah sesuatu yang dikerjakan atau produk atau jasa yang dihasilkan oleh seseorang atau kelompok, bagaimana mutu kerja, keteletian dan kerapian kerja, penugasan dan bidang kerja, penggunaan dan pemeliharaan peralatan, inisiatif dan kreativitas, disiplin, dan semangat kerja (kejujuran, loyalitas, rasa kesatuan dan tanggung jawab serta hubungan antar pribadi).

Dengan demikian dapat dikatakan bahwa prestasi kerja merupakan sejumlah output dari outcomes yang dihasilkan suatu kelompok atau organisasi tertentu baik yang berbentuk materi (kuantitatif) maupun yang berbentuk nonmateri (kualitatif). Pada organisasi atau unit kerja dimana input dapat teridentifikasi secara individu dalam bentuk kuantitas misalnya pabrik jamu, indikator kinerja pekerjaannya dapat diukur dengan mudah, yaitu banyaknya output yang dicapai dalam kurun waktu tertentu. Namun untuk unit kerja kelompok atau tim, kinerja tersebut agak sulit, dalam hubungan ini Simamora mengemukakan bahwa kinerja dapat dilihat dari indikatorindikator sebagai berikut: 1) keputusan terhadap segala aturan yang telah ditetapkan organisasi, 2) dapat melaksanakan pekerjaan atau tugasnya tanpa kesalahan (atau dengan tingkat kesalahan yang paling rendah), 3) ketetapan dalam menjalankan tugas ukuran kinerja secara umum yang kemudian deterjemahkan kedalam penilaian perilaku secara mendasar meliputi: (1) mutu kerja; (2) kuantitas kerja; (3) pengetahuan tentang pekerjaan; (4) pendapat atau pertanyaan yang disampaikan; (5) keputusan yang diambil; (6) perencanaan kerja; (7) daerah organisasi kerja. ${ }^{6}$

Masalah kinerja selalu mendapatkan perhatian dalam manajemen karena sangat berkaitan dengan produktivitas lembaga atau organisasi. Sehubungan dengan itu maka upaya untuk mengadakan penilaian kinerja merupakan hal yang sangat terpenting.

${ }^{5}$ Henry Simamora, (2004), Manajemen Sumber Daya Manusia, Edisi III (STIE YPKN Yogyakarta), h. 423.

$$
{ }^{6} \text { Ibid. }
$$


Pengukuran kinerja merupakan penilaian suatu proses kumajuan pekerjaan terhadap pencapaian tujuan dan sasaran yang telah ditentukan, termasuk informasi atau efisiensi penggunaan sumber daya dalam menghasilkan barang dan jasa, kualitas barang dan jasa perbandingan hasil kegiatan dengan target, dan efektivitas tindakan dalam mencapai tujuan. Dalam hal ini penting untuk ditentukan apakah tujuan pengukuran adalah untuk menilai hasil kerja (performance outcome) ataukah menilai perilaku (personality). Oleh karena itu, suatu organisasi seharusnya membedakan antara (hasil) (outcome), perilaku (process), dan alat pengukur yang tepat. Pengukuran kinerja paling tidak harus mencakup tiga variabel penting yang harus dipertimbangkan, yaitu perilaku (process), hasil (output) yakni produk langsung atau suatu aktivitas/program, dan (performance ) yakni dampak aktivitas/program. Ketiga cakupan pengukuran ini menjadi sangat penting sebagai variabel yang tidak dapat dipisahkan dan saling tergantung satu dengan lainnya sebagai bagian dari manajemen kinerja. ${ }^{7}$

Pengukuran kinerja meliputi aktivitas penetapan serangkaian ukuran atau indikator kinerja yang memberikan informasi sehingga memungkinkan bagi unit kerja soktor publik untuk memonitor kinerjanya dalam menghasilkan output dan outcome terhadap masyarakat. Pengukuran kinerja bermanfaat untuk membantu manejer unit kerja dalam memonitor dan memperbaiki kinerja dan berfokus pada tujuan organisasi dalam rangka memenuhi tuntutan akuntabilitas publik.

Pengukuran kinerja disektor publik menarik untuk diperbincangkan secara luas, terbuka dan mendalam karena pengukuran kinerja sektor public bukan sesuatu yang sederhana, namun sangat kompleks dan multidimensional. Pengukuran kinerja sektor public dalam beberapa hal berbeda dengan sektor swasta. Di sektor swasta, tujuan utama organisasi lebih jelas yaitu menghasilkan laba sebagai bottom line yang dapat diukur dengan ukuran finansial. Keberadaan organisasi bisnis adalah untuk menjual barang dan jasa dalam rangka menciptakan kekayaan dan kesejahteraan bagi pemiliknya. Berbeda dengan organisasi sektor public, kehadiranya dalah untuk memperbaiki kehidupan masyarakat denga cara memberikan pelayanan terbaik yang hal itu seringkali sulit diukur dengan ukuran financial.

Perhatian terhadap kinerja organisasi sektor publik menjadi sangat pentig karena pengukuran kinerja memiliki kaitan yang erat dengan akuntabilitas publik. Hasil kerja organisasi sektor

\footnotetext{
${ }^{7}$ Robertson (2002), John Isaac Mwita (2000), dalam Mahmudi (2007), Manajemen Sektor Publik (UPPM STIM YPKN, Yogyakarta), h. 6.
} 
publik harus dilaporkan dalam bentuk laporan pertanggung jawaban kinerja. Pembuatan laporan tersebut merupakan manifestasi dilakukannya akuntabilitas kinerja. Akuntabilitas kinerja memiliki kaitan yang sangat erat dengan konsep manajemen berbasis kinerja, karena manajemen berbasis kinerja menghendaki organisasi sektor publik untuk membuat sistem akuntabilitas berbasis hasil (results-based accountability system). ${ }^{8}$

Organisasi yang ingin melakukan pengukuran terhadap kinerjanya membutuhkan pentahapan proses sistematis. Untuk itu, perlu dibuat desain sistem manajemen kinerja untuk mencapai kinerja optimal ataupun memuaskan. Tahapan kinerja tersebut meliputi; 1). Tahap perencanaan kinerja; 2). Tahap pelaksanaan kinerja; 3). Penilaian kinerja; 4). Tahap review kinerja; 5). Tahap perbaikan kinerja. Berikut ini adalah tampilan tahap kinerja dalam gambar.

\section{KOMPETENSI PROFESIONAL}

Kompetensi dosen merupakan salah satu faktor yang mempengaruhi tercapainya tujuan pembelajaran dan pendidikan, namun kompetensi dosen tidak berdiri sendiri, dipengaruhi oleh faktor-faktor lain, seperti latar belakang pendidikan, pengalaman mengajar dan lama mengajar. Kompetensi dosen dinilai penting sebagai alat seleksi dalam penerimaan calon dosen, yang dapat dijadikan sebagai pedoman dalam rangka pembinaan dan pengembangan tenaga dosen.

Houston dalam Samana, menjelaskan bahwa kompetensi dosen kemampuan yang ditampilkan oleh dosen dalam melaksanakan kewajibannya memberikan pelayanan pendidikan kepada masyarakat. ${ }^{9}$ Cooper, dalam Sudjana, membagi empat kompetensi dosen, yaitu (1) mempunyai pengetahuan tentang belajar dan tingkah laku manusia; (2) mempunyai pengetahuan dan menguasai bidang studi yang dibinanya; (3) mempunyai sikap yang tepat tentang diri sendiri, teman sejawat dan bidang studi yang binanya; dan (4) mempunyai keterampilan teknik mengajar. ${ }^{10}$ Crasser, dalam Sudjana, membagi empat hal yang harus dikuasai dosen, yaitu: (1) menguasai bahan pelajaran; (2) kemampuan mendiagnosa tingkah laku siswa; (3) kemampuan melaksanakan proses pengajaran; dan (4) kemampuan mengukur hasil belajar siswa. ${ }^{11}$

Kompetensi dosen berkaitan dengan profesionalisme yaitu dosen yang profesional adalah dosen yang komponen (berkemampuan). Karena itu kompetensi profesional dosen dapat

\footnotetext{
${ }^{8} \mathrm{Ibid}$, h. 7.

${ }^{9}$ A. Samana (1994), Dasar-dasar Proses Belajar Mengajar (Sinar Baru Alge

${ }^{10}$ Nana Sudjana (1989), Dasar-dasar proses Belajar Mengajar (Sinar Baru Algesindo, Bandung), h. 18.

${ }^{11} \mathrm{Ibid}$, h. 18.
} 
diartikan sebagai kemampuan dan kewenangan dosen dalam menjalankan profesi dengan kemampuan tinggi. Seorang profesional adalah orang yang melakukan tugasnya keterampilan dan pemahaman. Di samping itu, seorang professional adalah seseorang yang memiliki tingkat kompetensi yang tinggi sehingga ia wajar mendapatkan bayaran keahlian yang dimilikinya.

Berbicara tentang kedudukan dosen sebagai tenaga profesional, maka berkaitan dengan profesi secara umum profesi dapat diartikan sebagai suatu pekerjaan yang memerlukan pendidikan lanjutan didalam science dan teknologi yang digunakan sebagai perangkat dasar untuk diimplementasikan dalam berbagai kegiatan yang bermanfaat. ${ }^{12}$ Lebih lanjut dijelaskan, seorang pekerja profesional termasuk dosen harus memiliki presepsi filosofis dan ketanggapan yang bijaksana yang lebih mantap dalam menyikapi dan melaksanakan pekerjaannya. Sehingga kompetensi dosen ditandai dengan serentetan diagnosa, rediagnosa, dan penyesuain yang terus menerus. Di samping itu, dosen hendaklah cermat dalam menentukan langkah, sabar, ulet dan telaten serta tanggap setiap kondisi, sehingga diakhir pekerjaannya akan membuahkan hasil yang memuaskan. ${ }^{13}$

Sehubungan dengan profesionalisme, Chourmain membagi tiga belas makna profesional, yaitu (1) melayani masyarakat sebagai jabatan karir sepanjang hayat; (2) berbasis ilmu dan keterampilan tertentu (3) berbasis hasil penelitian dan perapan teori dan praktek; (4) memerlukan adanya pendidikan dan pelatihan yang mendalam; (5) pengendalian disiplin dengan sejumlah persyaratan; (6) kemandirian dalam pengambilan keputusan; (7) meneriman dan memikul tanggung jawab; (8) memiliki komitmen terhadap pekerjaannya; (9) ada sistem dan produser kerja jelas; (10) ada asosiasi profesi; (11) ada sistem kode etik; (12) kepercayaan dan ketergantungan kepada diri sendiri; dan (13) ada status sosial tertentu yang jelas dan transparan. ${ }^{14}$

Sedangkan Wolmer dan Mills, seperti yang dikutip Sardirman, mengemukakan bahwa pekerjaan dapat dikatakan sebagai suatu profesi apabila memenuhi kriteria atau ukuran-ukuran sebagai berikut:

1) Memiliki spesialisasi dengan latar belakang teori yang luas, maksudnya, yaitu memiliki (a) pengetahuan umum yang luas; dan (b) keahlian yang mendalam.

\footnotetext{
12 Sardiman A.M. (1994), Interaksi dan Motovasi Belajar Mengajar: Pedoman Bagi Guru dan Clon Guru (PT. Raja Grafindo Persada, Jakarta), h. 131.

${ }^{13}$ Ibid.

${ }^{14}$ M.A.S. Imam Chourmain (2002), "Hand Out Kuliah” (Program Doktor Pasca Sarjana Universitas Negri Jakarta).
} 
2) Merupakan yang dibina secara organisatoris, maksudnya (a) adanya keterikatan dalam suatu organisasi professional; (b) memiliki otonomi jabatan; (c) memiliki kode etik jabatan; dan (d) merupakan karya bakti seumur hidup.

3) Diakui masyarakat sebagai pekerjaan yang mempunyai status profesional, maksudnya, (a) memperoleh dukungan masyarakat; (b) mendapatkan pengesahan dan perlindungan hukum; (c) memiliki persyaratan kerja yang sehat; dan (d) memiliki hidup yang sehat. ${ }^{15}$

Westby dan Gibson dalam Sardiman secara khusus menjelaskan cirri-ciri keprofesian di bidang pendidikan, yaitu sebagai berikut:

1) Diakui oleh masyarakat dan layanan yang diberikan itu hanyadikerjakan oleh pekerjaan yang dikategorikan sebagai suatu profesi.

2) Dimilikinya sekumpulan bidang ilmu pengetahuan sebagai landasan dari sejmlah teknik dan produser yang unik. Seperti harus mempelajari psikologi, metodik, dan sebagainya.

3) Diperlukan persiapan yang sengaja dan sistematis, sebelum orang itu dapat melaksanakan pekerjaan professional.

4) Dimilikinya mekanisme untuk menyaring sehingga orang berkompoten saja yang diperbolehkan professional.

5) Dimilikinya organisasi profesional untuk meningkatkan layanan kepada masyarakat. ${ }^{16}$

Berkaitan dengan itu, Soedijarto menjelaskan bahwa kompetensi dosen professional, menurut dosen untuk mampu menganalisis, mendiagnosis, memproganosis situasi pendidikan. Dosen yang memiliki kompetensi profesional perlu menguasai (1) disiplin ilmu pengetahuan sebagai sumber bahan pelajaran; (2) bahan ajar yang diajarkan; (3) pengetahuan tentang karakteristik siswa; (4) pengetahuan tentang filsafat dan tujuan pendidikan; (5) pengtahuan dan penguasaan metode dan model mangajar; (6) pengetahuan terhadap prinsip-prinsip teknologi pendidikan; (7) pengetahuan terhapap penilaian dan mampu merencanakan, memimpin, guna kelancaran proses pendidikan. ${ }^{17}$

Kompetensi utama yang harus dikuasai dosen adalah membelajarkan peserta didik. Namun demikian, kompetensi ini tidak berdiri sendiri, terpisah dari kemampuan yang lain karena untuk

\footnotetext{
${ }^{15}$ Sadirman A.M., op.cit, h. 131-132.

${ }^{16}$ Ibid, h. 132.

${ }^{17}$ Soedijarto (1993), Memantapkan Sistem Pendidikan Nasional (Gramedia Widiasarana, Jakarta), h. 60-61.
} 
mengajar di kelas diperlukan kemampuan yang mendasariny. Surya dalam Hadiyanto mengemukakan Sembilan karakteristik citra dosen yang ideal, yaitu: (1) memiliki semangat juang yang tinggi disertai kualitas keimanan dan ketakwaan yang mantap; (2) mampu mewujudkan dirinya dalam keterkaitan dan padanan dengan tuntutan lingkungan dan perkembangan iptek; (3) mampu belajar dan bekerjasama dengan profesi lain; (4) memiliki etos kerja yang kuat; (5) memiliki kejelasan dan kepastian pengembangan jenjang karir; (6) berjiwa professional yang tinggi; (7) memiliki kesejateraan lahir dan batin, material, dan non material; (8) memiliki wawasan masa depan; dan (9) mampu melaksanakan fungsi dan peranannya secara terpadu. ${ }^{18}$ Sedangkan Tilar, menjelaskan bahwa dosen pada abad 21 haru mempunyai; (1) kepribadian yang matang dan berkembang; (2) menguasai ilmu pengetahuan dan teknologi yang kuat; (3) ketrampilan untuk membangkitkan minat peserta didik, dan (4) mengembangkan profesinya secara berkesinambungan. ${ }^{19}$

Depniknas, menjelaskan bahwa tugas dosen sebagai pendidik dan pengajara memerlukan beberapa kompetensi atau kemampuan yang sesuai seperti kompetensi kepribadian, bidang studi, dan pendidikan/pembelajaran. Kemempuan Kepribadian; mencakup kepribadian yang utuh, berbudi luhur, dewasa, beriman, bermoral, kemampuan mengatualisasikan diri seperti disiplin, tanggung jawab, peka, objektif, luwes, berwawasan luas, dapat berkomunikasi dengan orang lain, mampu mengembangkan profesi semisal berpikir kreaktif, kritis, reflektif, mau belajar sepanjang hayat, dapat mengambil keputusan dan lain-lain. Kemampuan ini lebih menyangkut jati diri seorang dosen sebagai pribadi yang baik, bertanggung jawab, terbuka, dan terus mau belajar untuk maju. Kemampuan bidang studi memuat pemahaman akan karakteristik dan isi bahan ajar, menguasai konsepnya, mengenal metodologi ilmu yang bersangkutan, memahami konteks bidang itu dan juga kaitanya dengan masyarakat, lingkuan dan dengan ilmu lain. Kemampuan dalam pendidikan/Pembelajaran; memuat pemahaman akan sifat, cirri anak didik dan perkembangannya, mengerti beberapa konsep pendidikan yang berguna untuk membantu siswa, menguasai beberapa metodologi mengajar yang sesuai dengan bahan dan perkembangan siswa, serta menguasai sistem evaluasi yang tepat dan baik yang pada gilirannya semakin meningkatkan kemampuan siswa. ${ }^{20}$

Jakarta), h. 12

${ }^{18}$ Hadiyanto (2004), Mencari Sosok Desentralisasi Manajemen Pendidikan di Indonesia (Rineka Cipta,

${ }^{19}$ Ibid, h. 16

${ }^{20}$ Paul Suparno (2004), Guru Demokratis di Era Reformasi (Grafindo, Jakarta), h. 47-52. 
Secara umum dosen harus memunuhi dua kategori, yaitu memiliki kapabilitas dan loyalitas. Kapabilitas, yakni dosen harus memiliki kemampuan dalam bidang ilmu yang diajarkannya, memiliki kemampuan teoritik tentang tentang mengajar yang baik; mulai perencanaan, implementasi sampai evaluasi. Loyalitas, yakni loyal terhadap tugas-tugas; tidak semata di dalam kelas, tapi sebelum dan sesudah kelas. ${ }^{21}$

Dosen yang baik itu harus memenuhi tujuh kriteria, yaitu (1) sifat, dosen harus memilki sifat antusias, stimulatif, mendorong siswa untuk maju, hangat, berorientsi pada tugas dan bekerja keras, toleran, sopan, dan bijaksana, bisa dipercaya, fleksibilitas dan mudah menyesuaikan diri demokratis, penuh harapan bagi siswa, tidak mencari reputasi pribadi, mampu mengatasi stereotype siswa, mampu menyampaikan perasaannya, dan memiliki pendengaran yang baik; (2) pengetahuan, dosen juga memiliki pengetahuan yang memadai pada pelajaran yang diampunya, dan terus mengikuti kemajuan dalam bidang ilmunya itu; (3) apa yang disampaikan, dosen mampu memberikan jaminan bahwa materi yang disampaikannya mencakup semua unit bahasan yang diharapkan siswa secara maksimal; (4) bagaimana mengajar, dosen dalam menjelaskan berbagai informasi secara jelas, dan terang, memberikan layanan yang variatif, menggunakan kelompok kecil secara efektif, mendorong semua siswa berpartisipasi; (5) harapan, dosen mampu memberikan harapan pada siswa, membuat siswa akuntabel, dan mendorong partisipasi orang tua dalam memajukan kemampuan akademik siswanya; (6) reaksi dosen terhadap siswa, dosen bisa menerima berbagai masukan, resiko, dan tantangan, selalu memberikan dukungan pada siswanya, konsisten dalam kesepakatan dengan siswanya; dan (7) manajemen, dosen mampu menunjukan keahlian dalam perencanaan, memiliki kemampuan mengorganisasi kelas sejak hari pertama dia bertugas, cepat memulai kelas, melewati masa transisi dengan baik, memiliki kemampuan dalam mengatasi dua atau lebih aktivitas kelas dalam satu waktu yang sama.

Sedangkan Chourmain menjelaskan, kemampuan dasar dosen ada sepuluh kemampuan: (1) menguasai bahan pelajaran; (2) mengelola program belajar mengajar; (3) mengelola kelas; (4) menggunakan media/sumber; (5) menguasia landasan-landasan kependidikan; (6) mengelola interaksi belajar mengajar; (7) menilai prestasi siswa untuk kepentingan pengajaran; (8) mengenal fungsi dan program pelayanan bimbingan dan penyeluhan; (9) mengenal dan

\footnotetext{
${ }^{21}$ Dede Rosyada (2004), Paradigma pendidikan Demokratis: Sebuah Model Pelibatan Masyarakat Dalam Penyelenggaraan Pendidikan (kencana, Jakarta), h.112
} 
menyelenggarakan administrasi; dan (10) memahami prinsip-prinsip dan mentafsirkan hasil-hasil penelitian pendidikan guna keperluan pengajaran. ${ }^{22}$

Untuk dapat melaksanakan peran dosen di era globalisasi, Sidi menjelaskan bahwa sosok dosen masa depan harus bekerja secara professional. Dosen yang professional dituntut sejumlah persyaratan minimal, yakni memiliki; (1) kualifikasi keilmuan sesuai dengan bidang yang ditekuninya; (2) kmampuan berkomunikasi yang baik dengan anak didik; (3) jiwa kreatif dan produktif; (4) etos kerja dan komitmen tinggi terhadap profesi; dan (5) selalu mengambangkan did secara terus menerus melalui organisasi profesi, internet, buku, seminar, dan sebagainya. ${ }^{23}$

Berdasarkan pembahasan diatas maka untuk menjadi dosen yang memiliki kompetensi, seseorang harus memiliki berbagai kriteria atau sifat-sifat yang pelukan untuk profesi, yaitu antusias, stimulatif, mendorong siswa untuk maju, hangat, beroientasi pada tugas dan pekerja keras, toleran, sopan, dan bijaksana, bisa dipercaya dan sebagainya. Dosen juga harus memiliki kemampuan memadai dalam bidang ilmu yang akan diajarkannya, yakni memiliki penguasaan bidang ilmu dan loyal dengan ilmu tersebut, yakni terus mengikuti perkembangan dengan senantiasa meningkatkan keilmuannya lewat bacaan, menulis dan sebagainya.

\footnotetext{
22 Imam Chourmain,op.cit.

${ }^{23}$ Indra Djati Sidi (2001), Menuju Masyarakat Belajar: Menggagas Paradigma Baru Pendidikan (Paramadina, Jakarta), h.38-39.
} 


\section{DAFTAR PUSTAKA}

1. Robbins, Stephen P. (2002), Perilaku Organisasi, Edisi Indonesia, Jakarta: PT, Indeks.

2. Mangkunegara, A.P. (2005), Perilaku dan Budaya Organisasi, Bandung: Rosdakarya.

3. Prawirosentono, S. (1999), Kebijakan Kinerja Karyawan, Edisi I, Yogyakarta: BPFE.

4. Henry Simamora, (2004), Manajemen Sumber Daya Manusia, Edisi III, STIE YPKN Yokyakarta.

5. Robertson (2002), John Isaac Mwita (2000), dalam Mahmudi (2007), Manajemen Sektor Publik, UPPM STIM YPKN, Yogyakarta.

6. A. Samana (1994), Profesionalisme Keguruan Kanisius Yokyakarta

7. Nana Sutjana (1989), Dasar-dasar Proses Belajar Mengajar, Sinar Baru Algesindo, Bandung.

8. Sardiman A.M. (1994), Interaksi dan Motivasi Belajar Mengajar: Pedoman Bagi dan Calon Guru, PT. Raja Grafindo Persada, Jakarta.

9. M.A.S Imam Chourmain (2002), Hand Out Kuliah, Program Doktor Pascasarjana Universitas Negeri Jakarta.

10. Soedirjato (1993), Memantapkan Sistem Pendidikan Nasional, Gremedia Widiasarana, Jakarta.

11. Hadiyanto (2004), Mencari sosok Desentralisasi Manajemen Pendidikan di Indonesia, RinekaCipta, Jakarta.

12. Paul Suparno (2004), Guru Demokratis di Era Reformasi, Grasindo, Jakarta

13. Dede Rosyada (2004), Paradigma Pendidikan Demokratis: Sebuah Model Pelibatn Masyarakat dalm Penyelenggara Pendidikan, Kencana, Jakarta.

14. Indra Djati Sidi (2001), Menuju masyarakat Belajar ; Mengangas Paradigma Baru Pendidikan, Paramadina, Jakarta. 